Al-Huquq: Journal of Indonesian Islamic Economic Law, 3 (1), 2021: 52-80

ISSN: 2715-0003; E-ISSN 2714-5514

DOI: http://doi.org/10.19105/alhuquq.v3i1.4178

\title{
Analisis Faktor Internal Perusahaan dalam Efisiensi BMT di Indonesia Perspektif Syariah Compliance
}

\author{
M. Fuad Hadziq, Erika Amelia \\ (Program Studi Ekonomi Syariah Universitas Terbuka, Jalan Raya Pamulang \\ Tangerang Selatan, Banten, 15437)
}

\begin{abstract}
Abstrak:
Berdasarkan fakta di lapangan, saat ini banyak BMT kurang berkembang dan mengalami kepailitan. Hal itu disebabkan faktor internal seperti manajemen usaha, manajemen sumber daya manusia, laporan keuangan serta pengawasan. Riset ini bertujuan menganalisis faktor yang mempengaruhi efisiensi BMT dilihat dari faktor internalnya ditinjau dari syariah compliance. Adapun metode riset menggunakan deskriptif analisis dengan kritis mengelaborasi data lapangan secara langsung melalui deep interview \& observasi ke manajer keuangan, karyawan serta direktur. Adapun samplingnya menggunakan metode judgement di BMT Pulau Jawa yang merupakan pulau berpenduduk terbanyak di Indonesia. Efisiensi dilakukan dengan menganalisis variabel input dan output yaitu aset likuid, total pembiayaan, pendapatan bagi hasil, biaya operasional, beban tenaga kerja pembiayaan dan aset tetap. Hasil riset menyatakan BMT belum efisien secara keseluruhan. Permasalahan BMT terletak pada tata kelola manajemen, sumber daya manusia, laporan keuangan serta pengawasan. Inefisiensi terutama disebabkan biaya operasional dan biaya tenaga kerja. Beberapa BMT belum melakukan manajerial sumber daya manusia secara profesional. BMT belum melakukan efisiensi terstruktur dan terjadwal. Efisiensi hanya dilakukan dengan pengurangan biaya operasional dan perjalanan dinas. Belum ada standar baku dalam standar efisiensi, serta tidak adanya aturan pemerintah atau regulator dalam efisiensi terutama di laporan keuangan. Strategi efisiensi dilakukan terutama dalam pengurangan dan meminimalkan biaya perjalanan, tidak untuk biaya tenaga kerja. Dalam syariah compliance, BMT sebagai entitas koperasi syariah harus mengikuti peraturan KUKM dalam PSAK, SAK Syariah dan SAK ETAP. Mengingat BMT adalah berbasis syariah maka BMT wajib menggunakan SAK syariah karena SAK ETAP tidak
\end{abstract}

email koresproden: fuadhadziq@ecampus.ut.ac.id

https://creativecommons.org/licenses/by-nc/4.0/

Copyright (c) 2019 by al-huquq. All Right Reserved 
mengatur transaksi syariah serta PSAK yang 27 yang telah dicabut. (Based on the facts, currently many BMTs are not growth and bankruptcy. This is due to internal factors such as business management, human resource management, financial reports and supervision. This article aims to analyze the factors that affect the efficiency of BMT seen from internal factors in terms of sharia compliance. The research method uses descriptive analysis by critically elaborating field data directly through deep interviews \& observations to financial managers, employees and directors. The sampling used the judgment method in BMT of Java Island, which is the most populous island in Indonesia. Efficiency is done by analyzing the input and output variables : liquid assets, total financing, revenue sharing, operating costs, financing labor costs and fixed assets. The results of the research state that BMT has not been efficient as a whole. The problem of BMT in management governance, human resources, financial reports and supervision. Inefficiency is basicly due to operational costs and labor costs. Some BMTs have not done professional human resource management. BMT has not carried out structured and scheduled efficiency. Efficiency is only done by reducing operational costs and official travel. There are no standard standards for efficiency standards, and there are no government regulations or regulators on efficiency, especially in financial reports. The efficiency strategy is carried out mainly in reducing and minimizing travel costs, not for labor costs. In sharia compliance, BMT as a sharia cooperative entity must follow KUKM regulations in PSAK, Sharia SAK and SAK ETAP. Considering that BMT is sharia-based, BMT is required to use sharia SAK because SAK ETAP does not regulate sharia transactions and PSAK which has been revoked.)

Kata Kunci:

Efisiensi, BMT, Internal, Syariah Compliance, SAK Syariah.

\section{Pendahuluan}

Perkembangan ekonomi syariah, utamanya dengan bank syariahnya telah menjadi salah satu pilar dalam ekonomi di Indonesia. Bermula dengan berdirinya bank muamalat yang dipelopori oleh Ikatan cendekiawan muslim Indonesia yang telah 
berusia 28 tahun. Akan tetapi sampai saat ini, usia yang sudah cukup tersebut tidak berimplikasi sama dengan market share ekonomi syariah. Per Oktober 2019, kisarannya masih sekitar 6.01\% yang dirilis oleh Otoritas Jasa Keuangan (OJK) yaitu sebesar 513 triliun rupiah ${ }^{1}$. Ikon terbesar dari ekonomi syariah adalah bank syariah. Sektor tersebut merupakan faktor terbesar dalam perekonomian sebuah negara, begitu pun juga ekonomi syariah. Dari sisi market share bank syariah juga masih minim dengan pasar bank konvensional. Dengan market share tersebut, jumlah ini berbanding terbalik dan jauh dari jumlah masyarakat muslim Indonesia yang mencapai $85 \%$. Sehingga hal ini akan terus menjadi ambigu dalam proses perkembangan ekonomi syariah di Indonesia. Begitu pula lembaga BMT (Baitul Maal wat tamwiil) yang core bisnisnya adalah syariah pula. Sehingga keterikatan BMT dengan bank syariah juga kuat, karena banyaknya persamaan seperti persamaan produk dan manajemen menggunakan prinsip syariah.

Indonesia merupakan negara dengan UMKM (Usaha Mikro, Kecil dan Menengah) yang banyak. Pembangunan sektor ekonomi sangat tergantung dari peran UMKM pula. Peran tersebut terbukti dengan tahannya sektor UMKM dalam menghadapi krisis ekonomi selama ini. Terbukti dengan tahan bantingnya BMT pada tahun krisis yaitu pada 1998-20092. Salah satu lembaga yang menyokong dalam perkembangan usaha kecil menengah adalah lembaga keuangan syariah. Alasan ini terbukti dengan BMT mempunyai tiga seperempat jaringan usaha mikro dan kecil di seluruh Indonesia ${ }^{3}$. Diketahui bahwa usaha kecil menengah mencapai 51,2 juta unit atau sekitar 99,91\% pelaku usaha di Indonesia. Fakta itu menjadi bukti bahwa UMKM merupakan ruh dari perekonomian Indonesia. BMT menjadi salah satu stake holder UMKM telah memberikan andil besar dalam

1 OJK, "Statistik Perbankan Syariah," Departemen Perizinan Dan Informasi Perbankan, 2019, https://www.ojk.go.id/id/kanal/syariah/datadan-statistik/statistik-perbankan-syariah/default.aspx. diakses pada 14 April 2020.

2 Ali Sakti, "Mapping of Condition and Potential of BMT: Partnership to Expand the Market and Linkage of Islamic Banking Services to the Micro Enterprises," Jurnal Al-Muzara'ah I, no. 1 (2013): 1-18.

3 Amin Aziz, Pedoman Pendirian BMT (Jakarta: Pinbuk Press, 2004), hlm. 2. 
kemajuan UMKM dan masyarakat Indonesia pada umumnya4. Sehingga peran BMT terbukti nyata dalam peningkatan kesejahteraan warga Indonesia, terutama masyarakat usaha kecil menengah.

Gambar 1 Lembaga Keuangan dan Sasaran Masyarakat Usaha

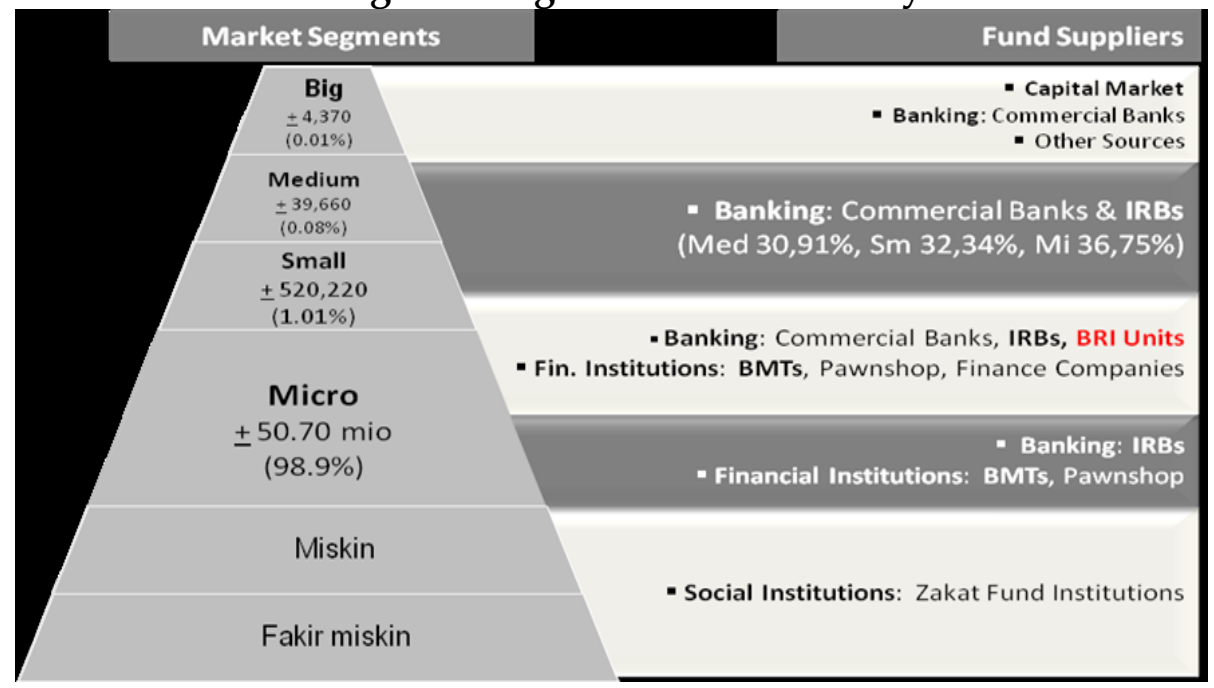

Sumber: Ali Sakti, Mapping of Condition and Potential of BMT: Partnership to Expand the Market and Linkage of Islamic Banking Services to the Micro Enterprises', Jurnal Al-Muzara'ah 5

Pada tahun 2012 jumlah BMT mencapai 3900 di seluruh Indonesia menurut Ketua Umum Dewan Pimpinan Pusat Perhimpunan BMT Indonesia. Selanjutnya jumlah BMT tersebut terus mengalami kenaikan sampai dengan 5500 BMT pada tahun $2013^{6}$. Jumlah tersebut merupakan kalkulasi perkiraan dari data asosiasi BMT Indonesia. Data itu merupakan data terkumpul yang dapat didata dari BMT yang menjadi anggota asosiasinya, sedangkan data

4 Sakti, "Mapping of Condition and Potential of BMT: Partnership to Expand the Market and Linkage of Islamic Banking Services to the Micro Enterprises. hlm. 1-18."

5 Sakti "Mapping of Condition and Potential of BMT: Partnership to Expand the Market and Linkage of Islamic Banking Services to the Micro Enterprises. hlm. 1-18".

6 M. Z. Mughal, "Empowering SMEs for Financial Inclusion and Growth," in Internasional Conference "Empowering SMEs for Financial Inclusion and Growth (Jakarta, 2014). 
yang di luar asosiasi juga masih banyak. Sehingga jumlah pasti keseluruhan BMT tidak dapat diketahui, begitu pun juga data dari kementerian koperasi dan UKM. Sehingga bisa diasumsikan bahwa jumlah BMT lebih banyak dari yang sebenarnya tercatat. Gambaran tersebut ditambah dengan segmen pasar yang sangat luas. Sehingga utility dan pengaruhnya terhadap kelangsungan dunia usaha juga sangat besar.

Banyak sekali permasalahan utama BMT di Indonesia. Salah satu permasalahan utamanya adalah manajemen tata kelola. Hal tersebut dapat mempengaruhi performa dan keberlanjutan BMT. Buruknya tata kelola menyebabkan buruk pula performa BMT. Sebagai lembaga kepercayaan, persepsi masyarakat mempunyai stigma negatif terhadapnya ${ }^{7}$. Pada saat ini pula, persepsi itu telah terjadi di UMKM. Tata kelola UMKM tergolong masih belum profesional, sehingga berdampak pada minimnya pembiayaan yang didapat UMKM ${ }^{8}$.

Sebagai lembaga keuangan profesional, banyak faktor dalam naik turunnya usaha di BMT. Riset Dieter melihat industri BMT menghadapi problem yang sangat besar terutama dalam aspek pengaturan dan pengawasan yang lemah. Selain itu, persepsi berkinerja buruk ke mayoritas BMT dianggap menjadi penyebab pada kecenderungan negatif serta mengarahkan pada kebangkrutan'. Beberapa aspek mulai dari produk, dana pihak ketiga, pembiayaan, manajemen sumber daya manusia, laporan keuangan usaha dan lain sebagainya. Salah satu faktor terpenting dari beberapa aspek yang menjadi permasalahan BMT adalah faktor pembiayaan dan tata kelola BMT. Seperti riset sebelumnya dari Ismail dan Widiyanto dalam Afif bahwa tata kelola BMT menjadi penyebab dalam turunnya performa BMT $^{10}$.

7 Vini Sapta Noor, Analisis Perbandingan Efisiensi Bank Syariah Dan Bank Konvensional Dengan Menggunakan Metode Data Envelopment Analysis (DEA), 2013, hlm. 43.

8 Wildan Syafik Afif and Darwanto, "Tata Kelola Baitul Maal Wa Tamwil (BMT) Studi Pada BMT Mekar Da ' Wah" 1, no. July (2017): 121-38.

9 Hans Dieter and Dwi Agung, "Islamic Microfinance in Indonesia," 2006, hlm. 37.

10 Afif and Darwanto, "Tata Kelola Baitul Maal Wa Tamwil (BMT) Studi Pada BMT Mekar Da ' Wah, hlm, 121-38" 
Kenyataan di praktik lapangan menunjukkan banyak BMT yang mati dan bubar disebabkan berbagai hal, antara lain karena manajemen yang kurang profesional dan jauh dari sifat amanah $^{11}$. Tata kelola sangat erat kaitannya dengan sumber daya manusia (SDM). Banyak BMT memperkerjakan SDM yang tidak sesuai dengan bidangnya. Sehingga menyebabkan profesional BMT tidak sesuai dengan kemampuan kepakarannya. Akibatnya, banyak BMT yang bangkrut dari buruknya SDM karena ketidaktahuan tentang pekerjaan yang mereka kerjakan.

Sebagai lembaga kepercayaan, BMT diharuskan mempunyai efisiensi setinggi mungkin. Selain itu pula, ia juga harus memiliki kinerja yang baik ${ }^{12}$. Maka dari itu, faktor yang mendukung dan menghambat efisiensi sangat penting diamati dan dianalisis. Adanya efisiensi dalam operasional akan meningkatkan output yang dihasilkan. Operasional yang efisien akan memaksimalkan output yang nantinya dihasilkan. Salah satu indikator efisiensi lembaga keuangan adalah beberapa rasio NIM, CAR, ROA, BOPO dan ROE.

Salah satunya adalah rasio keuangan $\mathrm{BOPO}$, ia digunakan untuk mengukur tingkat efisiensi dari sisi usaha manajemen BMT. Lembaga dalam contoh ini adalah bank. Non efisien ditunjukkan dari $\mathrm{BOPO}$ tinggi. Lembaga yang BOPO tinggi jika terus menyalurkan kredit, maka lembaga akan mendapati negatif interest rates spread. Pada kondisi ini, lembaga akan mengurangi pembiayaan. Tujuannya meminimalkan rugi, lalu mengalihkan investasi ke surat berharga atau fee based income sehingga sementara waktu meniadakan fungsi lembaga intermediasi ${ }^{13}$. Dalam kondisi ini sebenarnya tidak berbeda jauh dengan kegiatan yang dilakukan di BMT karena ia merupakan lembaga yang hampir sama, yaitu sama-sama lembaga intermediasi.

${ }^{11}$ B.S. Santoso, “Analisis Tingkat Kesehatan BMT Ditinjau Dari Aspek Manajemen," Jurnal Akuntansi-Bisnis \& Manajemen 14, no. 4 (2003): 144-58.

12 Adrian Sutawijaya and Etty puji Lestari, "Efisiensi Teknik Perbankan Indonesia Pascakrisis Ekonomi: Sebuah Studi Empiris Penerapan Model DEA," Jurnal Ekonomi Pembangunan 10, no. 1 (2009): 49-67.

13 Muliaman D Hadad et al., Pendekatan Parametrik Untuk Efisiensi Perbankan Indonesia (Universitas Indonesia, 2003), Universitas Indonesia, hlm, 1-26. 
UMKM sangat dekat dan erat dengan BMT. Hampir sebagian besar nasabahnya adalah berasal dari UMKM. Salah satu alasannya adalah positioning market BMT di usaha level kelas menengah ke bawah. Beberapa kondisi di lapangan, pembiayaan dari BMT mempunyai imbal hasil yang besar. Bahkan di beberapa wilayah mencapai $2 \%$ per bulan. Akan tetapi dari kucuran pembiayaan yang dilakukan tidak sebesar yang diharapkan keuntungan ke BMT. Sehingga tantangan utama BMT saat ini dalam efisiensi adalah peningkatan dalam pengaturan dan pengawasan BMT ${ }^{14}$. Perlu dilakukan pembenahan dan penguatan dalam tata kelola BMT sehingga efisiensi BMT akan terus naik berbanding sama dengan bank pada umumnya.

Dalam pembenahan dan penguatan BMT dibutuhkan suatu sistim pengelolaan yang andal berupa sistem tata kelola perusahaan yang baik, biasa disebut Good Corporate Governance (GCG). GCG ialah salah satu mekanisme tata kelola organisasi secara efisien, efektif dan ekonomis dengan prinsip terbuka, akuntabilitas, tanggung jawab, independen dan adil. Prinsip-prinsip dalam melaksanakan GCG yang baik itu meliputi keadilan, transparansi, akuntabilitas, tanggung jawab dan etika serta budaya kerja ${ }^{15}$. Topik utamanya adalah akuntabilitas serta tanggung jawab, salah satunya terhadap laporan keuangan ${ }^{16}$.

GCG bisa dikatakan salah satu prinsip dari syariah compliance atau kepatuhan syariah. Fungsi pengawasan merupakan salah satu bentuk dari prinsip kepatuhan syariah. Tidak hanya melalui dewan pengawas syariah saja, tetapi prinsip GCG terutama akuntabilitas dan tanggung jawab harus selalu dipegang oleh BMT. Bisa dikatakan bahwa pertumbuhan BMT yang kurang maksimal, perlu dicermati dan diteliti dari sisi aspek GCG yang kurang maksimal. Terutama dalam akuntabilitas laporan keuangan BMT yang perlu diperbaiki

14 Sakti, "Mapping of Condition and Potential of BMT: Partnership to Expand the Market and Linkage of Islamic Banking Services to the Micro Enterprises, hlm. 1-18."

15 Sjafri Mangkuprawira, "Rumitnya Tata Kelola Perusahaan," accessed June 25, 2021, http://ronowajah.wordpress.com.

${ }^{16}$ Kasmir, Manajemen Perbankan (Jakarta: PT Raja Grafindo Persada, 2003), hlm, 133. 
dari sisi penerapan peraturan dan sistematika laporan keuangannya. Penerapan GCG dalam manajemen BMT diharapkan dapat membawa dampak positif terutama dalam aspek kepatuhan syariah.

Salah satu prinsip dari GCG adalah akuntabilitas dan tanggung jawab. BMT sebagai lembaga finansial selalu menggunakan laporan keuangan sebagai basis dan modal dalam laporan setiap waktunya. Laporan keuangan yang berkualitas adalah laporan keuangan yang sesuai dengan prinsip akuntansi yang berlaku umum dan memenuhi aturan yang ada dan DPS menjamin kredibilitas laporan keuangan ${ }^{17}$. Laporan keuangan memiliki peran sebagai sumber informasi kepada para pihak yang membutuhkan informasi dari laporan keuangan tersebut. Laporan keuangan digunakan oleh BMT sebagai alat peningkat kredibilitas. Karena, menyajikan laporan keuangan kepada publik, dapat meningkatkan kepercayaan masyarakat untuk menjadi nasabah dari sebuah bank maupun BMT.

Pada faktanya, banyak BMT yang kurang bisa berkembang, bangkrut bahkan banyak yang mati dalam kelangsungan usahanya. Sehingga bisa diasumsikan berarti penyaluran pembiayaan BMT tidak efisien. Ada hal salah, baik dalam tata kelola keuangannya, manajemen organisasi sumber daya manusianya atau pelaporan keuangannya. Lebih lanjut perlu diteliti faktor internal dalam perusahaan tersebut yang berkaitan dengan faktor-faktor yang terjadi di dalam perusahaan dilihat dari sisi syariah compliance. Faktor tersebut meliputi organisasi manajerial, sumber daya manusia dan laporan keuangan BMT. Seluruh hal tersebut dilihat dari sisi kepatuhan syariahnya. Sehingga luaran riset akan didapatkan gambaran utama yang jelas dan detail dalam hal tersebut dan akan didapatkan saran serta solusi tepat dalam perbaikan institusi BMT.

\section{Metode Penelitian}

Dalam riset ini merupakan jenis riset kualitatif yang mengelaborasi hasil wawancara secara mendalam kemudian dianalisis secara deskriptif analisis. Metode ini mengungkapkan gambaran yang sistematik, jelas dan mendalam dari permasalahan faktual di lapangan. Ia berasal dari problem riset yang dianalisis

17 Suhardjono Bastian Indra, Akuntansi Perbankan (Jakarta: Salemba Empat, 2006), hlm. 60. 
dengan kritis sehingga memberikan gambaran fakta utuh terhadap objek problem riset ${ }^{18}$. Riset ini meneliti dari hasil pengamatan fenomena di lapangan langsung dari sumber primernya yaitu stake holder BMT. Metode pengumpulan datanya menggunakan literatur pustaka dari jurnal sebelumnya, dokumentasi lapangan, deep interview dan observasi langsung ke objek riset. Deep interview dilakukan ke manajer keuangan, karyawan, direktur dan nasabah BMT.

Adapun penentuan sampel diperoleh BMT di Indonesia yang datanya dilaporkan di pusat inkubator bisnis (Pinbuk). Adapun sampling riset ini menggunakan sampel judgement, provinsi di Indonesia dengan penduduk terbesar dan BMT terbanyak di Indonesia yaitu di pulau Jawa. Pada riset ini, unit kerja yang digunakan adalah 5 BMT besar di Indonesia yaitu BMT An Najah Pekalongan, BMT Bintaro Jakarta Selatan, BMT AL Munawaroh Banten, BMT Mekar Dakwah Banten, dan BMT Sido giri Pasuruan. Selain itu, BMT ini tergolong baik dalam pelaporan keuangannya, dalam artian mengeluarkan laporan keuangan dalam setiap periodenya. Ia aktif dalam melaporkan laporan keuangannya, baik ke anggota BMT maupun pengawas eksternal. Dari penilaian tersebut, periset berasumsi BMT tersebut cukup sesuai dengan syarat sampel sebuah riset.

Adapun variabel yang dilakukan dalam analisis efisiensi dari perspektif syariah compliance adalah variabel input dan output.

Tabel 1. Variabel riset

\begin{tabular}{ll}
\hline Jenis & Variabel \\
\hline Output 1 & Aset likuid \\
Output 2 & Total Pinjaman pembiayaan \\
Output 3 & Pendapatan Bagi Hasil Pembiayaan \\
Input 1 & Biaya Operasi Pembiayaan \\
Input 2 & Beban Tenaga Kerja Pembiayaan \\
Input 3 & Aset tetap \\
\hline
\end{tabular}

Sumber : Diolah penulis

18 Badratun Nisak, "Analisis Manajemen Risiko Pembiayaan Musyarakah Pada Baitul Qiradh Bina Insan Mandiri Banda Aceh," Share 3, no. 1 (2014): 41-55. 
Lalu analisis datanya menggunakan proses riset kualitatif yaitu membuat koding, melakukan tabulasi data, interpretasi data, dan terakhir melakukan pengambilan kesimpulan data. Di dalamnya lebih melihat dari sisi deskriptif gambaran tabel perbandingan setiap variabel dari rasio keuangannya. Data tersebut dibuat secara deskriptif dari perbandingan variabel output dan input. Analisis data menggunakan induktif yaitu dari umum ke khusus, karena periset menginginkan kesimpulan lebih komprehensif dan menyeluruh dalam penemuan luaran hasil riset.

\section{Baitul Mal wat Tamwiil}

Pembiayaan merupakan pemberian dana ke pihak tertentu dalam tujuan investasi sebuah perusahaan. Adapun tujuan investasi di antaranya memaksimalkan laba, meminimalkan risiko, pemberdayaan ekonomi dan penyaluran dana yang lebih ${ }^{19}$. BMT merupakan salah satu lembaga swadaya masyarakat. Dalam definisi lain, BMT berdiri dan berkembang oleh masyarakat sendiri. Terutama pada awal berdirinya, BMT berasal dari sumber daya anggota, baik itu dana atau pun modal awal dari masyarakat ${ }^{20}$.

Pada dasarnya, BMT adalah persilangan dari dua lembaga yaitu baitul maal dan lembaga baitut-tamwil. Usahanya dalam pengembangan usaha produktif dan investasi di sektor usaha kecil menengah dengan mendorong tabungan masyarakat dan pembiayaan ekonomi. Kegiatan Baitul Maal adalah menerima titipan dana zakat, infak dan sedekah yang kemudian mengelolanya sesuai dengan aturan syariat dan amanahnya. Dari sisi lembaga sosial, zakat, infak dan sedekah diorganisir BMT bagi kesejahteraan masyarakat ${ }^{21}$.

Produk BMT mengacu pada Fatwa Dewan Syariah Nasional-

19 Heny Yuningrum, "Mengukur Kinerja Operasional BMT Pada Tahun 2010 Ditinjau Dari Segi Efisiensi Dengan Data Envelopment Analysis (DEA) (Studi Kasus BMT Di Kota Semarang)," Jurnal Economica II, no. 2 (2012): 111-28.

20 Aziz, Pedoman Pendirian BMT, hlm. 2.

21 Novita Dewi Masyithoh, "Analisis Normatif Undang-Undang No. 1 Tahun 2013 Tentang Lembaga Keuangan Mikro (Lkm) Atas Status Badan Hukum Dan Pengawasan Baitul Maal Wat Tamwil (Bmt)," Economica: Jurnal Ekonomi Islam 5, no. 2 (2014): 17-36. 
Majelis Ulama Indonesia (DSN-MUI). Produk tersebut hampir sama dengan bank konvensional, tetapi ada sub khusus yaitu zakat, infak dan sedekah. Di dalamnya ada produk pengumpulan dana, lending, dan investasi. Tetapi salah satu bagian yang paling utama adalah produk penyaluran dana atau pembiayaan, karena kapasitas aspek tersebut sangat berpengaruh terhadap kinerja BMT secara global ${ }^{22}$. Adapun akad utama yang digunakan adalah akad murabahah, mudharabah, ijarah dan akad musyarakah. Dalam praktik di akuntansi penerapannya menggunakan PSAK 102, 105 dan 106. Untuk lebih singkatnya dijelaskan dalam gambar di bawah ini.

Gambar 2. Perhimpunan, penyaluran dan pendapatan usaha BMT

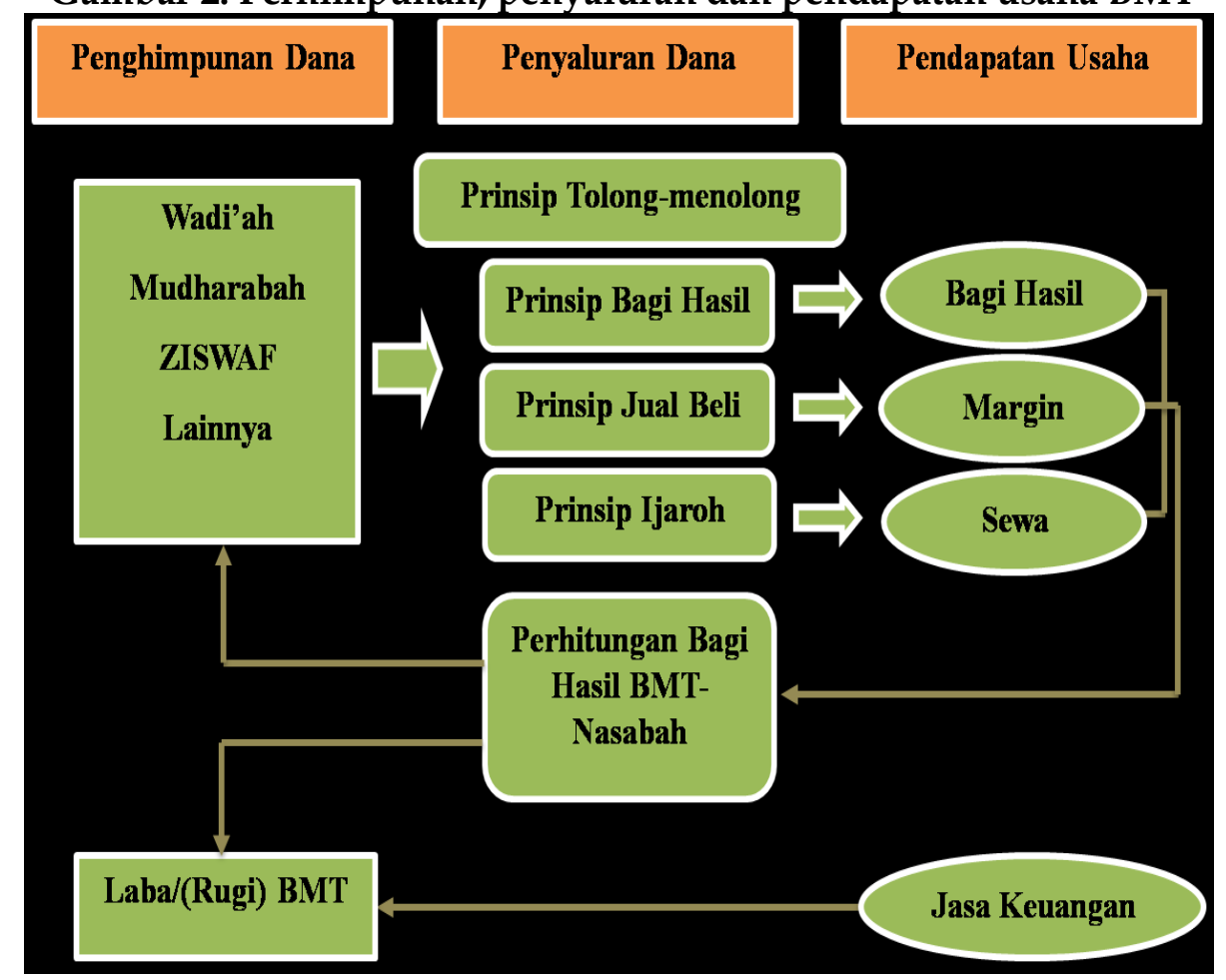

Sumber : Sumber BMT Bismillah

22 Fitriani Prastiawati and Emile Satia Darma, "Peran Pembiayaan Baitul Maal Wat Tamwil Terhadap Perkembangan Usaha Dan Peningkatan Kesejahteraan Anggotanya Dari Sektor Mikro Pedagang Pasar Tradisional," Jurnal Akuntansi Dan Investasi 17, no. 2 (2016): 197-208. 


\section{Efisiensi}

Satu dari sekian banyak parameter kerja dalam pengukuran kinerja bank dan perusahaan adalah dengan metode efisiensi. Perhitungan kerja yang sulit dipecahkan oleh solusi dalam efisiensi, contohnya efisiensi alokasi, teknologi dan efisiensi total ${ }^{23}$. Secara spesifik, efisiensi adalah kemampuan dalam menyelesaikan sebuah pekerjaan yang benar. Secara matematis, analisis dari rasio input, bisa juga diartikan jumlah yang dihasil dari sebuah input yang telah dilakukan.

Efisiensi teknis adalah satu dari sekian banyak efisiensi ekonomi dari banyak aspek yang ada. Tetapi efisiensi teknis adalah salah satu syarat efisiensi ekonomi secara keseluruhan. Sehingga perusahaan harus menghasilkan output maksimal dari input tertentu (efisiensi teknis) serta menghasilkan output dari perpaduan tepat dari harga tertentu (efisiensi alokatif) ${ }^{24}$.

Selain itu terdapat juga cost efficiency yang mengukur tingkat biaya lembaga keuangan lalu dibandingkan dengan lembaga lain yang memiliki operasi terbaik yang memproduksi output sama dari teknologi yang sama pula. Selain itu pula, ada juga profit efficiency yang mengukur efisiensi perusahaan dari kemampuannya menghasilkan laba dari unit yang telah dikeluarkan. ${ }^{25}$

Adapun faktor dalam efisiensi lembaga keuangan dapat diperinci menjadi 4 faktor menurut Tobin yang dikutip Priyonggo Suseno, di antaranya: arbitrase informasi, efisiensi ketepatan penilaian aset, efisiensi dari antisipasi risiko dan terakhir efisiensi karena administrasi dan mekanisme pembayaran (efisiensi fungsional). Di dalamnya termasuk general insurance, risk pooling, administrasi dan mobilisasi dana masyarakat ${ }^{26}$.

23 Hadad et al., Pendekatan Parametrik Untuk Efisiensi Perbankan Indonesia, hlm, 1-26.

${ }^{24}$ Ascarya and Yumanita, "Comparing The Development of Islamic Financial / Bond Markets in Malaysia and Indonesia," Development, no. October (2016): 375-407.

25 Priyonggo Suseno, "Analisis Efisiensi Dan Skala Ekonomi Pada Industri Perbankan Syariah Di Indonesia.," Pusat Pengkajian Dan Pengembangan Ekonomi Islam 2 (2008): 25-55.

${ }^{26} \mathrm{Ibid}, \mathrm{hlm}, 25-55$. 
Model efisiensi dalam sektor finansial terdiri dari tiga konsep dasar yaitu standard profit efficiency, cost efficiency dan alternative profit efficiency. Standard profit efficiency merupakan pengukuran hasil keuntungan maksimal lebih khusus dari perbandingan input dan output. Sedangkan Cost efficiency pengukuran tingkat biaya dibandingkan dengan best practiced cost yang menghasilkan output yang sama dengan kondisi yang sama pula. Sedangkan alternative profit efficiency mengukur bagaimana bank mendapatkan pendapatan maksimum dengan tingkat output dibanding dengan harga output 27. Ia juga menyatakan bahwa pendekatan intermediasi merupakan pendekatan yang lebih tepat untuk mengevaluasi kinerja lembaga keuangan sebagai financial intermediation.

Tujuan efisiensi yaitu berusaha mencapai keuntungan optimal. Sekilas, efisiensi dalam Islam tidak dikenal secara detail. Penekanan biaya setinggi-tingginya dengan tujuan mendapatkan keuntungan akan mengakibatkan perbuatan zalim yang tidak sesuai dengan ruh Islam. Prinsip Islam menganjurkan usaha tersebut harus tetap menjaga keseimbangan (ta'adul) serta etika syariah. Keuntungan seharusnya seimbang dengan kerja keras dan beban ${ }^{28}$.

Efisiensi dalam dunia perbankan merupakan satu dari sekian banyak parameter kinerja yang banyak digunakan dalam menghitung ukuran-ukuran kinerja lembaga keuangan. Begitu juga dengan pengukuran efisiensi di BMT karena sama-sama termasuk lembaga keuangan. Beberapa metode tersebut menunjukkan tingkat kinerja yang baik akan tetapi tidak masuk dalam kriteria sehat atau sesuai dengan peraturan. Beberapa contoh metode tersebut adalah Capital Adequacy Ratio (CAR), Reserve Requirement, Legal Lending Limit dan kredibilitas para pengelola bank. Di samping itu, ada beberapa metode parametrik yang acap kali digunakan seperti metode

27 Allen N Berger and David B Humphrey, "Efficiency of Financial Institutions: International Survey and Directions for Future Research," European Journal of Operational Research 98 (1997): 175-212.

${ }_{28} \mathrm{M}$ Mahbubi Ali, Stei Tazkia, and Bank Indonesia, "Analisis Efisiensi Baitul Maal Wat Tamwil Dengan Pendekatan Two Stage Data Envelopment Analysis ( Studi Kasus Kantor Cabang BMT MMU Dan BMT UGT Sidogiri )" 5, no. 2 (2010): 110-25. 
parametrik, ada 2 pendekatan untuk menghitung efisiensi, yaitu stochastic frontier approach (SFA) dan distribution free approach (DFA) ${ }^{29}$.

\section{Syariah Compliance}

Dalam syariah compliance, institusi yang berhubungan erat dan berpengaruh adalah dewan pengawas syariah. Dalam hal pelaksanaannya, dewan pengawas syariah diangkat oleh rapat umum pemegang saham atas rekomendasi Majelis Ulama Indonesia. Ia berfungsi untuk memberikan opini terhadap tingkat kepatuhan institusi pada aturan syariah. Keberadaannya juga menjadi salah satu ciri yang membedakan bank syariah dengan bank konvensional. DPS merupakan lembaga independen atau hakim khusus dalam fikih muamalat, namun DPS bisa juga anggota di luar ahli fikih tetapi ahli juga dalam bidang lembaga keuangan Islam dan fikih muamalat, DPS suatu lembaga keuangan yang berkewajiban mengarahkan, meneliti, dan mengawasi aktivitas lembaga keuangan agar dapat di yakinkan bahwa mereka mematuhi aturan dan prinsip syariah Islam.

Peran DPS sangat menentukan dalam mengawasi operasi bank syariah agar tetap memenuhi prinsip-prinsip syariah (sharia compliance). Lemahnya peran Dewan Pengawas Syariah, sering kali menimbulkan terjadinya penyimpangan syariah yang dilakukan oleh manajemen bank syariah ${ }^{30}$. Bank syariah masih banyak yang melakukan praktik riba yang diharamkan. Padahal, idealnya bank syariahlah yang menjadi lokomotif lembaga keuangan anti riba, tapi justru di bank syariah itu pula terdapat praktik riba ${ }^{31}$.

\section{Standar Akuntansi Keuangan Syariah}

Pertumbuhan lembaga ekonomi syariah kian bertambah pesat dari waktu ke waktu. Tidak hanya perbankan syariah, tetapi juga merambah ke lembaga keuangan syariah lainnya seperti pegadaian, leasing, asuransi dan lainnya. Dalam penggunaan peraturannya,

29 Hadad et al., Pendekatan Parametrik Untuk Efisiensi Perbankan Indonesia, hlm, 1-26.

30 Sofyan Safri Harahap, Auditing Dalam Perspektif Islam (Jaka: Pustaka Quantum, 2008), hlm, 207.

31 Agustianto Mingka, "Optimalisasi Dewan Pengawas Syariah," accessed June 25, 2021, www.niriah.com. 
tentu tidak semua sesuai dengan lembaga non syariah. Selain itu pula, entitas non bank seperti BMT juga tidak sesuai sepenuhnya jika menggunakan peraturan bank. Oleh karena latar belakang itu, MUI (Majelis Ulama Indonesia), IAI (Ikatan Akuntan Indonesia), akademisi dan para praktisi mencoba merumuskan standar akuntansi keuangan syariah $^{32}$. Kemudian dari landasan itu, muncullah SAK.

Pada awalnya SAK ditujukan kepada entitas baik syariah atau non syariah dalam pelaksanaan transaksinya. ${ }^{33}$ Ia mengacu pada model SAK Umum, tetapi basisnya tetap syariah serta mengacu ke fatwa MUI dengan dewan syariah nasional sebagai lembaga pengawas syariah. ${ }^{34}$ Kemudian PSAK telah banyak berkembang dan muncul sesuai urutan waktu. Di antaranya PSAK adalah PSAK 101 : Penyajian Laporan Keuangan Syariah 2. PSAK 102 : Akuntansi Murabahah 3. PSAK 103 : Akuntansi Salam 4. PSAK 104 : Akuntansi Istishna' 5. PSAK 105 : Akuntansi Mudharabah 6. PSAK 106 : Akuntansi Musyarakah 7. PSAK 107 : Akuntansi Ijarah 8. PSAK 108 : Akuntansi Transaksi Asuransi Syariah 9. PSAK 109 : Akuntansi Zakat dan Infak/Sedekah. ${ }^{35}$

Adapun organisasi yang mengeluarkan PSAK adalah ikatan ahli Indonesia (IAI). Ia adalah organisasi profesi akuntan resmi sebagai badan penyusun standar akuntansi keuangan ${ }^{36}$. Tujuan dibentuknya organisasi ini salah satunya adalah menyajikan, mengumumkan, dan menafsirkan standar akuntansi dan auditing untuk lembaga keuangan Islam dan meneliti serta mengubah standar akuntansi dan auditing untuk lembaga keuangan Islam. ${ }^{37}$ Dalam setiap proses

32 Purnama Putra, "Analisis Tingkat Pemahaman Mahasiswa Terhadap Pernyataan Standar Akuntansi Keuangan Syariah Psak-Syariah," JRAK 6, no. 01 (2015): 38-50.

${ }^{3}$ N Ula, "Analisis Implementasi Laporan Keuangan Berdasarkan SAK Syariah Pada Koperasi Perkreditan Rakyat Syariah (KPRS) An-Nahl Pandaan" (UIN Maulana Malik Ibrahim, 2019), hlm. 1-116.

${ }^{34}$ Ibid, hlm. 1-116.

35 Putra, "Analisis Tingkat Pemahaman Mahasiswa Terhadap Pernyataan Standar Akuntansi Keuangan Syariah Psak-Syariah, hlm, 38-50"

36 Nurfajdi Budi Nugroho, "Studi PSAK Perbankan Syariah: Telaah Kesesuaian Dengan Prinsip Dan Nilai Syariah" (Universitas Islam Indonesia, 2005), hlm, 1-185.

${ }^{37} \mathrm{Ibid}, \mathrm{hlm}, 1-185$. 
pengeluaran SAK, ia menyertai dengan kerangka dasar penyusunan dan penyajian laporan keuangan syariah (KDPPLKS) serta Pernyataan Standar Akuntansi Keuangan. Ia merupakan pengaturan akuntansi yang memberikan konsep dalam penyusunan dan penyajian laporan keuangan atas transaksi syariah. Selain itu pula, ia memberikan konsep paradigma dan asas transaksi syariah ${ }^{38}$.

\section{Analisis Faktor Internal BMT Perspektif Syariah Compliance}

Pada awalnya, BMT merupakan lembaga keuangan yang selayaknya mempunyai tata kelola dan manajemen yang baik sesuai lembaga keuangan pada umumnya. Tetapi saat ini, BMT tidak mempunyai ketentuan jelas yang mengatur serta lembaga pengawas resmi. Ia tidak diatur oleh Bank Indonesia secara detail seperti bank pada umumnya. BMT dalam pembentukannya cukup disahkan oleh kementerian Koperasi dan UMKM ${ }^{39}$. Denda dan punishment pun juga terbilang lemah dari peraturan yang telah ada. Sehingga efeknya banyak BMT mengalami tata kelola dan manajemen yang kurang baik, walaupun tidak secara keseluruhan. BMT dikelola dengan cara sederhana dengan sumber daya manusia yang terbatas. Dalam proses operasionalnya, BMT juga tidak terlalu bankable dibandingkan dengan bank lainnya yang sudah terstandarisasi. Sehingga performa tersebut menyebabkan turunnya performa BMT karena tata kelola BMT yang kurang baik. Lambat laun, persepsi BMT menjadi buruk di mata masyarakat karena tata kelola BMT yang kurang diperhatikan ${ }^{40}$.

\section{BMT An Najah, Jawa Tengah}

Secara garis besar, BMT An Najah merupakan BMT yang telah lama beroperasi artinya telah mengalami pengalaman yang cukup panjang dalam menjalankan usahanya. Dengan pengalam tersebut,

38 Ula, "Analisis Implementasi Laporan Keuangan Berdasarkan SAK Syariah Pada Koperasi Perkreditan Rakyat Syariah (KPRS) An-Nahl Pandaan, hlm. 1-116."

39 Sakti, "Mapping of Condition and Potential of BMT: Partnership to Expand the Market and Linkage of Islamic Banking Services to the Micro Enterprises, hlm. 1-18."

40 A. C Nasution, "Efficiency of Baitul Maal Wa Tamwil (BMT): An Effort towards Islamic Wealth Management in Microfinance Institution," The Journal of Muamalat and Islamic Finance Research 11, no. 1 (2014): 59-74. 
BMT ini terlebih dahulu mempunyai strategi dan taktik baik dalam proses pembiayaan, funding, penanganan kredit macet dan lain sebagainya dibandingkan dengan BMT lainnya. Bisa diasumsikan awal, dengan proses mitigasi risiko dan kelangsungan usahanya lebih mapan dan stabil dibandingkan BMT lainnya.

\section{Gambar 3. Analisa hasil efisiensi data BMT An Najah}

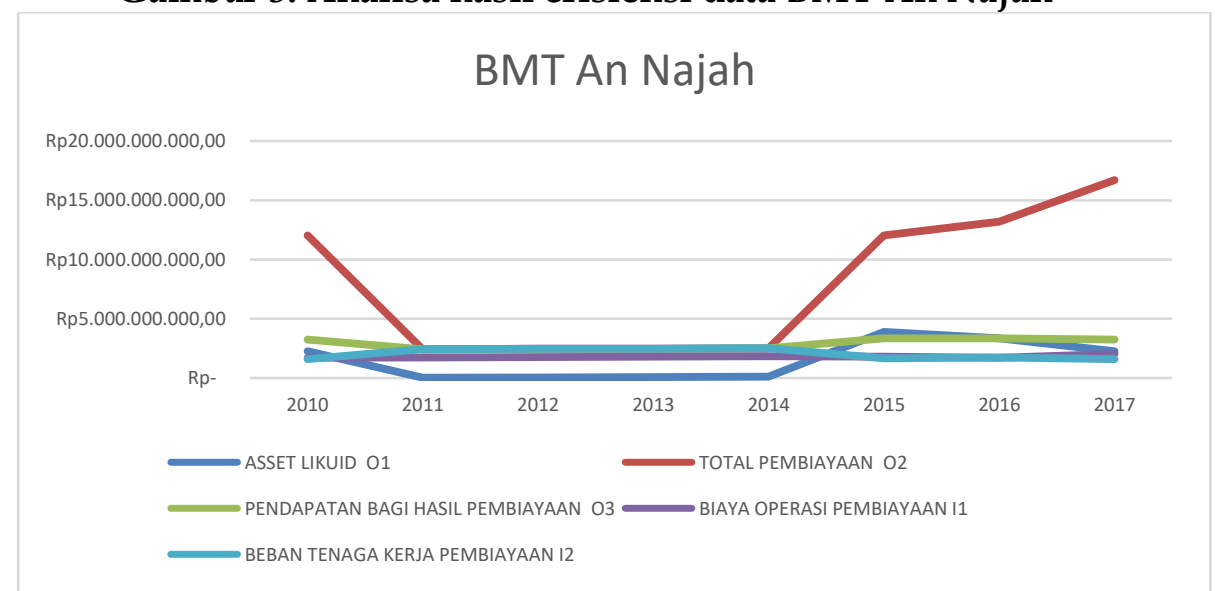

Sumber : data hasil riset yang diolah periset

Dari gambar di atas digambarkan bahwa total pembiayaan terus naik dari tahun ke tahun. Walaupun pada awalnya mengalami penurunan di awal tahun 2011, tetapi setelah itu mengalami perkembangan dari tahun ke tahun. Bahkan pada 2015-2017 mengalami perkembangan yang naik tajam sampai $400 \%$, 500\% dan $700 \%$ di tahun 2017. Artinya terdapat kas yang besar sehingga BMT bisa menggelontorkan pembiayaan yang cukup besar. Hasilnya pun cukup bisa dirasakan dari pendapatan bagi hasil juga mengalami perkembangan kenaikan walaupun tidak besar.

Tahun 2010 dan 2015-2016 BMT mengalami efisiensi, selainnya tahun tersebut BMT mengalami kurang efisien. Inefisiensi tersebut terlebih dikarenakan BOPO tinggi. Beban tenga kerja menjadi beban terbesar dari beban operasional lainnya. Beban tenaga kerja mengalami kenaikan setiap tahun. Walaupun demikian, hal tersebut wajar yang hampir terjadi di sebagian besar lembaga keuangan. Dari laporan keuangannya, BOPO masih stabil di bawah 70\%, tetapi kenaikan pembiayaan tidak signifikan. Sedangkan target kenaikan 
pendapatan masih kurang sesuai dengan proyeksi yang diharapkan oleh manajemen BMT. Pembiayaan naik bahkan sampai berlipat tetapi tanpa dibarengi dengan jumlah pendapatan bagi hasil dari pembiayaan yang naik tidak setimpal dengan jumlah pembiayaan. Dari hasil tersebut bisa terdapat indikasi kredit macet atau terjadi piutang yang besar yang tidak dapat diambil. Artinya terjadi tidak efisien dalam usahanya.

\section{BMT Bintaro, Jakarta}

BMT ini mempunyai produk pengumpulan dana seperti BMT pada umumnya, tetapi kurang terlalu berinovasi dan membuat produk baru sehingga terkesan tidak up to date dengan kebutuhan masyarakat. Dari sisi marketing, ia lebih melihat dari sisi optimalisasi nasabah lama dalam artian memberikan kepuasan kepada nasabah lama. Memberikan feed back serta memberikan kepuasan agar nasabah lama tidak pindah ke lembaga keuangan lainnya. Akan tetapi, BMT juga melakukan proyeksi nasabah baru. Hal ini bisa dikategorikan sebagai efisiensi teknis. Efisiensi teknis adalah satu dari sekian banyak efisiensi ekonomi dari banyak aspek yang ada. Tetapi efisiensi teknis adalah salah satu syarat efisiensi ekonomi secara keseluruhan ${ }^{41}$.

\section{Gambar 4. Analisa hasil efisiensi data BMT Bintaro}

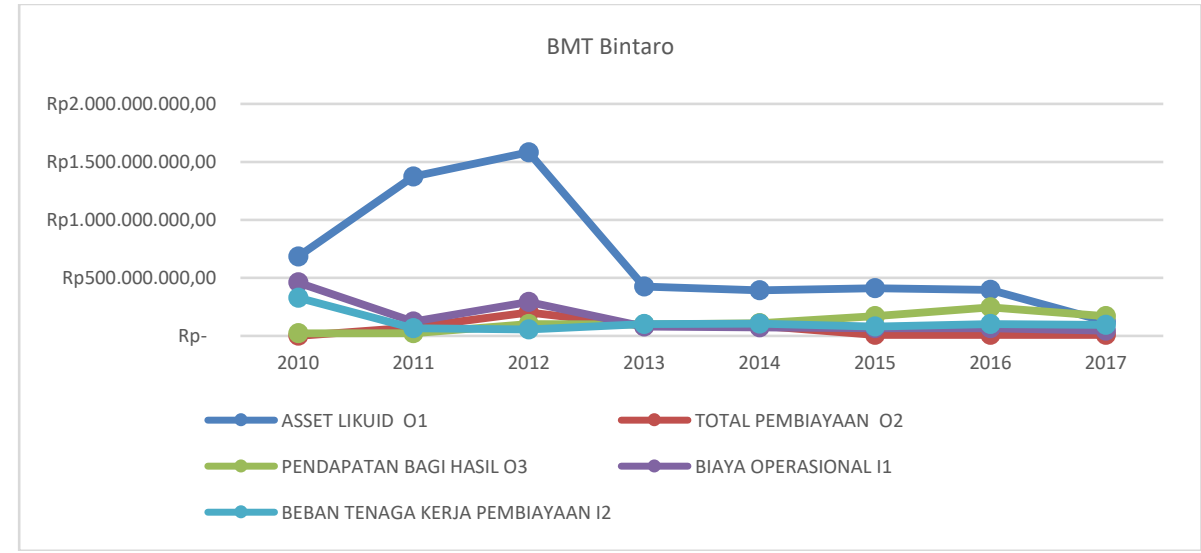

Sumber : data hasil riset yang diolah periset

41 D. Y Ascarya and S. R Guruh, Analisis Efisiensi Perbankan Konvensional Dan Perbankan Syariah Di Indonesia Dengan Data Envelopment Analysis (DEA) (Jakarta: Prenada Media Group, 2009), hlm, 1-34. 
BMT mengalami perlambatan terutama di aset likuid, sedangkan untuk variabel lainnya mengalami peningkatan walaupun tidak terlalu pesat. Salah satu kenaikan yang cukup tinggi adalah kenaikan terutama di pendapatan bagi hasil. Dari analisis efisiensi, BMT ini termasuk efisien, hanya 2 tahun tidak efisien selebihnya adalah efisien. Sehingga dari manajemen pembiayaan, BMT ini tergolong baik.

Hal lain yang patut untuk diketahui bahwa, pengelolaan dan manajerial BMT ini tidak hanya terfokus ke dalam usaha keuangan saja, melainkan BMT ini memanfaatkan jumlah modal yang cukup besar sebagai modal dalam berbisnis jual-beli barang. Dengan kata lain selain mendapatkan keuntungan dari sektor keuangan, BMT Bintaro juga mendapatkan keuntungan dari jual-beli barang. BMT ini memiliki strategi dan positioning yang berbeda dengan BMT yang lain. Ia lebih banyak melakukan jual beli barang dari pada melakukan pembiayaan ke nasabah. Sedangkan kebanyakan BMT lebih memilih tipikal usaha dalam pembiayaan dari pada jual beli. Ia lebih melihat dari sisi kondisi di sekitar BMT yang lebih prospek untuk jual beli. Selain itu banyaknya kompetitor dengan lembaga keuangan lainnya, membuat peluang pembiayaan lebih sedikit dalam melakukan pinjam meminjam. Dari segi positioning usaha, BMT ini telah melakukan efisiensi dengan memetakan kesulitan-kesulitan dalam penghitungan ukuran-ukuran kinerja, seperti tingkat efisiensi teknologi, alokasi, dan efisiensi total ${ }^{42}$.

\section{BMT Al Munawaroh, Banten}

Secara sekilas BMT ini terlihat stagnan dan stabil, tumbuh tapi tidak terlalu tinggi. Ia terus mengalami pertumbuhan dari tahun ke tahun, walaupun pertumbuhannya tidak mengalami perkembangan yang signifikan. Pertumbuhan pembiayaan dan pendapatan tidak sebanding dengan biaya operasi dan tenaga kerja. BMT ini dibilang sebanding antara efisien dan tidaknya pada tahun yang diteliti 2 tahun terakhir efisien

42 Hadad et al., Pendekatan Parametrik Untuk Efisiensi Perbankan Indonesia, hlm, 1-26. 


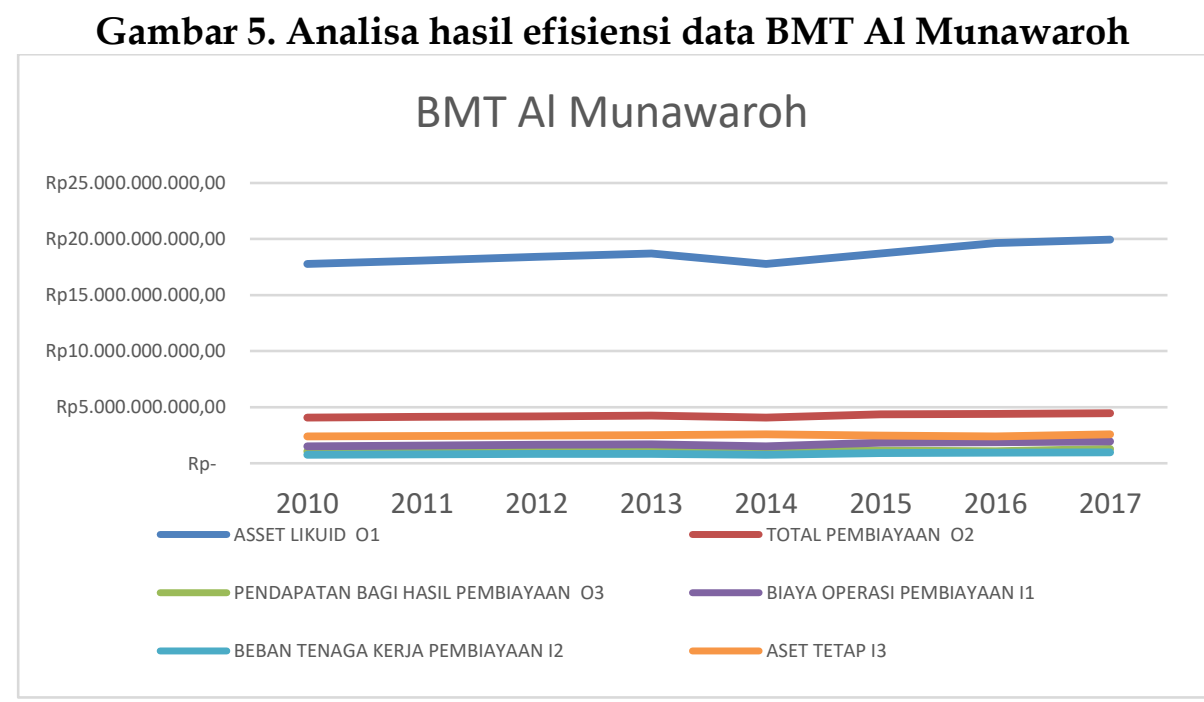

Sumber : data hasil riset yang diolah periset

Dari gambar di atas terlihat semua variabel mengalami perkembangan kenaikan dari tahun ke tahun. Akan tetapi perkembangan tersebut dirasakan tidak terlalu tinggi, bisa dikatakan sedang. Dilihat dari total pembiayaan mengalami kenaikan tapi tidak signifikan. Dilihat dari berkembangnya, BMT ini hati-hati dalam melakukan pembiayaan. Kehati-hatian tersebut diimbangi dengan beban biaya operasional dan beban tenaga kerja yang naik tetapi sedikit. Ia meminimalisir over head dari beban gaji pegawai yang besar dengan meminimalkan biaya gaji dengan tidak menaikkan gaji secara besar-besaran ataupun merekrut tenaga pegawai baru yang akan menambah pos dari beban gaji perusahaan.

\section{BMT Sidogiri, Jawa Timur}

BMT Sidogiri termasuk BMT terbesar di aset dan jumlah pembiayaan di Indonesia. BMT ini sangat berani melakukan ekstensifikasi usaha dengan pembukaan cabang di beberapa wilayah di Indonesia. Asetnya baik yang likuid dan non likuid tersebar sampai di titik terpencil di Indonesia. Ia menyasar pasar-pasar tradisional yang dihuni oleh usaha kecil menengah (UMKM). Menurutnya UMKM merupakan porsi nasabah terbesarnya sekaligus mitra terbaik dalam roda bisnisnya. Umurnya BMT juga sudah cukup 
lama dan cukup pengalaman dalam menjalankan bisnis di lembaga keuangan. Selain itu cabang BMT ini merupakan salah satu yang terbanyak di Indonesia terutama di Pulau Jawa.

Gambar 6. Analisa hasil efisiensi data BMT Sidogiri

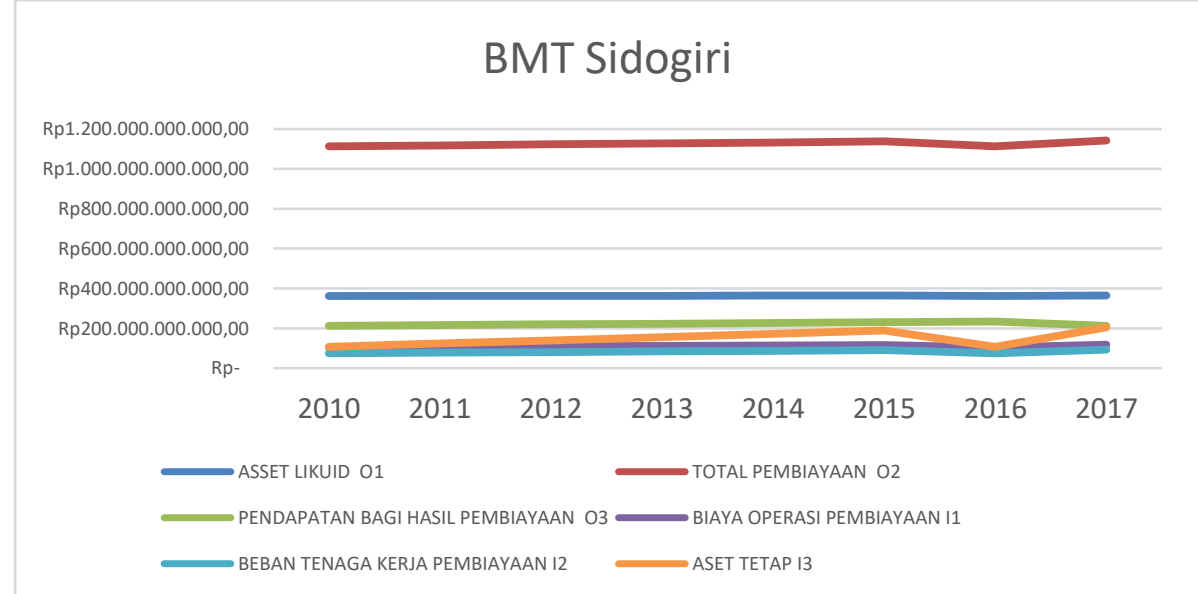

Sumber : data hasil riset yang diolah periset

Semua variabel mengalami peningkatan, tetapi sedikit tidak sebanding dengan proyeksi dan target yang telah ditentukan oleh manajemen BMT. Terlihat dari total pembiayaan yang besar dan terus mengalami kenaikan dari tahun ke tahun. Ia terus melakukan ekspansi usaha dengan membuka unit-unit usaha di daerah yang dianggap marketable. Hasilnya pun berbanding sama dengan bagi hasil pembiayaan yang diterima.

BMT ini tergolong salah satu terbesar asetnya di Indonesia, tetapi BMT ini termasuk tidak efisien karena besarnya BOPO dan kecilnya ROA. Dengan BOPO tinggi memperlihatkan lembaga keuangan ini non efisien yang jika masih melakukan penyaluran kredit, maka ia nantinya mengalami interest rates spread yang negatif. Dalam situasi ini ia selanjutnya mengurangi penyaluran kredit dalam tujuan meminimalisir kerugian berikutnya dan kemudian mengalihkan investasinya ke surat berharga atau fee based income sehingga mengesampingkan fungsi awal bank yaitu sebagai lembaga intermediasi (Hadad, 2003). Akan tetapi dari hasil observasi di lapangan serta deep interview dengan manajer keuangan, BMT ini 
telah berhasil memitigasi risiko usaha dan risiko pasar. Studi kelayakan dilakukan dengan beberapa indikator seperti jumlah UMKM, jarak kantor dengan pasar, kompetitor di sekitar usaha, behavior UMKM dan lain sebagainya. Hasilnya banyak cabang BMT yang masih stabil dan survive. Bahkan NPF atau kredit macet BMT ini tergolong baik di bawah $2 \%$.

\section{BMT Mekar Dakwah, Banten}

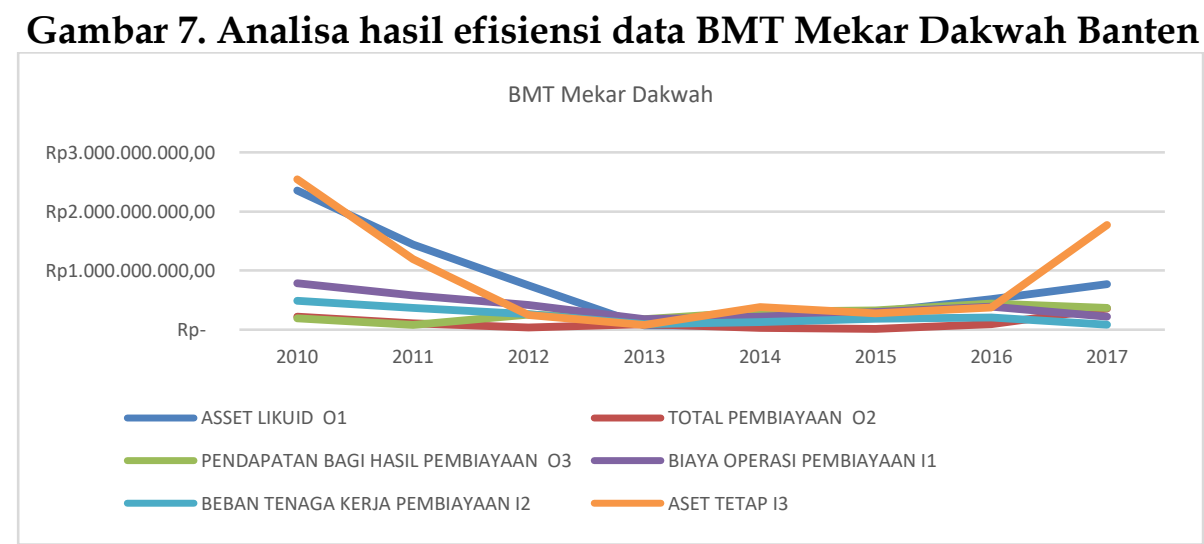

Sumber : data hasil riset yang diolah periset

Dari grafik di atas dapat dideskripsikan bahwa terjadi penurunan aset likuid dan aset tetap di awal tahun 2010-2011, akan tetapi setelah itu ada kenaikan di tahun 2016 dan tahun 2017. Beberapa kemungkinan di BMT tersebut terdapat pelepasan hak di aset, bisa juga dijual, dipinjamkan, dan bukan lagi menjadi aset BMT diubah ke kepemilikan individu dan lain sebagainya. Perlu diketahui, bahwa banyak BMT yang kurang baik dalam pencatatan asetnya. Kadang kala kepemilikan individu dan kepemilikan BMT masih bercampur aduk tidak dicatatkan dengan baik. Pada awalnya BMT merupakan badan yang berasal dari masyarakat menengah ke bawah, sehingga pola dalam pendiriannya banyak tata kelola manajemen rumah tangga. Beberapa aset awal seperti gedung, peralatan kantor, kendaraan dan lainnya masih bercampur dengan kepemilikan individu. Akibatnya ketika pencatatan laporan keuangan, aset tersebut masih tercatat di aset BMT padahal sebenarnya kepemilikan individu. 


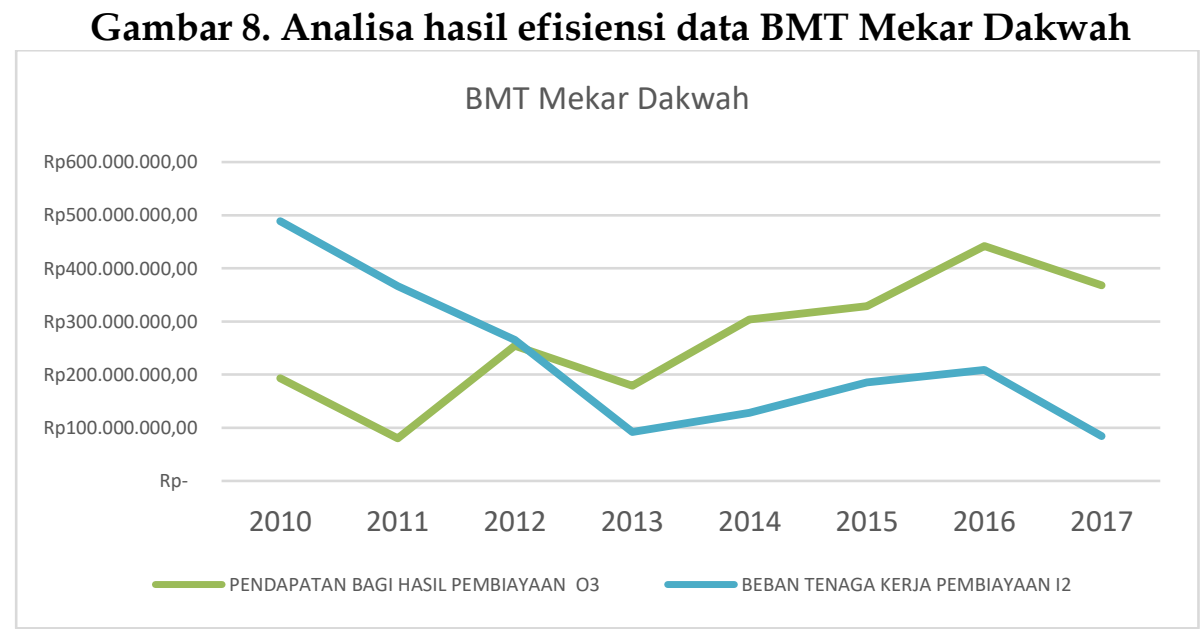

Sumber : data hasil riset yang diolah periset

Adapun variabel total pembiayaan, biaya operasional, pendapatan bagi hasil pembiayaan terbilang mengalami kenaikan tapi tidak terlalu signifikan. Pendapatan pembiayaan terlihat lebih banyak mengalami kenaikan dari akun lainnya. Biasanya ketika pendapatan naik akan diiringi oleh beban tenaga juga yang naik pula, akan tetapi dalam hal ini beban tenaga kerja malah turun dari tahun ke tahun. Secara sekilas terjadi efisiensi dalam proses pembiayaan yang dilakukan. Bisa dikatakan BMT ini tergolong hati-hati dalam mengelola bisnisnya. Ia tidak serta merta melakukan ekstensifikasi usaha ataupun menaikkan dana pembiayaan ke luar secara besarbesaran. Sehingga terlihat stabil dalam waktu yang lama. Di sisi lain beban tenaga kerja yang biasanya mengalami kenaikan drastis dan menjadi beban besar bisa diminimalkan, tetapi terlihat kenaikannya tidak terlalu besar bahkan ada tren menurun di akhir tahun 2017.

Secara keseluruhan BMT mengalami inefisiensi terutama dari biaya operasional dan biaya tenaga kerja. Kedua variabel tersebut mengalami kenaikan secara terus menerus dari tahun ke tahun dan jarang sekali mengalami penurunan. Ia menjadi beban biaya BMT yang terbesar dibandingkan beban-beban lainnya. Dari perspektif mikroekonomi, permasalahan ini tidak sesuai dengan definisi efisiensi yang bertujuan untuk menghemat tenaga dan biaya yang 
dikeluarkan ${ }^{43}$. Padahal pada dasarnya efisiensi menjadi solusi dalam kesulitan-kesulitan dalam penghitungan ukuran-ukuran kinerja ${ }^{44}$.

Banyak BMT melakukan manajerial sumber daya manusia secara tradisional. Karena efisiensi membutuhkan kualitas profesional dan kualitas moral yang harus dipenuhi dan saling melengkapi45. BMT Masih banyak merekrut SDM tidak sesuai dengan kepakaran dan kemampuannya. Bahkan merekrut SDM dari unsur famili yang tidak ada sangkut pautnya dengan kemampuannya, sehingga menjadi beban dalam tupoksi dalam kemampuan kepakaran pekerjaannya dan akhirnya menjadi beban dalam beban gaji di akhir karena tidak tegasnya BMT dalam mengatur SDM-nya. Lambat laun, BMT menjadi tidak efisien karena menanggung beban gaji karyawan yang besar. Oleh karena itu, banyak BMT yang BOPO tinggi dikarenakan akibat dari beban gaji yang besar. Walaupun total pendapatan naik tapi untuk beban operasional dan beban pembiayaan melebihi total kenaikan dari pendapatan, sehingga dikatakan tetap belum efisien.

BMT belum melakukan efisiensi secara terstruktur dan terjadwal. Hal tersebut dilakukan karena belum ada standar baku dalam standar efisiensi, serta tidak adanya aturan dari pemerintah atau regulator yang jelas dan mengikat. Dari observasi dan deep interview di lapangan, belum diketemukan secara detail tentang dokumen dalam proses efisiensi. Efisiensi dilakukan dengan pengurangan biaya operasional dan perjalanan dinas. Karena wujud dari efisiensi adalah tercipta pada efektivitas kerja yaitu adanya hasil yang dicapai sesuai proses yang telah dilakukan sebelumnya yaitu antara rasio output dan input. Efisiensi tidak dilakukan untuk biaya tenaga kerja, walaupun variabel tersebut. Walaupun sebenarnya efisiensi telah dilakukan dalam beberapa aspek operasional BMT.

${ }^{43}$ Vini Sapta Noor, Analisis Perbandingan Efisiensi Bank Syariah Dan Bank Konvensional Dengan Menggunakan Metode Data Envelopment Analysis (DEA), 2013, hlm. 43.

44 Hadad et al., Pendekatan Parametrik Untuk Efisiensi Perbankan Indonesia, hlm, 1-26.

45 Almizan, "Pembangunan Ekonomi Dalam Perspektif Ekonomi Islam," Maqdis : Jurnal Kajian Ekonomi Islam 1, no. 2 (2016): 204-22. 


\section{Syariah Compliance BMT}

BMT yang merupakan bagian dari entitas bisnis berdasarkan syariah memerlukan akuntansi yang didasarkan syariah juga ${ }^{46}$. Seperti halnya lembaga syariah lainnya, ia juga harus tunduk patuh terhadap peraturan syariah, tetapi harus pula patuh dengan aturan konvensional selagi tidak bertentangan dengan syariah. Hal ini karena informasi akuntansi syariah dapat mengakomodasi keadaan lembaga keuangan yang dijalankan dengan kerangka syariah secara menyeluruh, sebagai akibat dari hakikat transaksi yang berbeda dengan lembaga keuangan konvensional ${ }^{47}$.

Ada banyak peraturan yang mengatur tentang keberadaan lembaga keuangan syariah, tidak terkecuali BMT. Pada dasarnya banyak sekali peraturan yang mengatur tentang kelembagaan BMT dalam entitas sebagai koperasi. Setidaknya ada dua permen KUKM (Kementerian Koperasi dan Usaha Kecil dan Menengah) yang telah dikeluarkan yang berkaitan dengan akuntansi koperasi yaitu Permen KUKM No.04/per/M.KUKM/VII/2012 tentang Pedoman Akuntansi dan Permen KUKM No. 35.2/PER/M.KUKM/X/2007 Tentang Pedoman Standar Operasional Manajemen KJKS (Koperasi jasa keuangan syariah) dan UJKS (Unit jasa keuangan syariah).

Di Indonesia, secara legalitas hampir seluruh BMT yang ada memiliki badan hukum koperasi. Karena perlu ditekankan, bahwasanya karakteristik BMT bisa dikatakan mirip koperasi, atau juga mirip dengan bank. Terlihat dari produk yang ditawarkan seperti bank dan koperasi, tetapi ia mempunyai kekhususan dengan adanya produk zakat, infak dan sedekah. Acuan BMT sebagai koperasi turut serta menjadi pertimbangan dalam PSAK yang mengaturnya. Sebelum tahun 2011, standar akuntansi keuangan entitas koperasi mengacu pada PSAK 27 mengenai Akuntansi Koperasi, dan pada tanggal 8 April 2011, terdapat Pernyataan Pencabutan Standar Akuntansi Keuangan 8 (PPSAK 8) oleh DSAK (Dewan Standar Akuntansi Keuangan) untuk mencabut PSAK 27.

${ }^{46}$ Hasbi Ramli, Edukasi Profesional Syariah, Teori Dasar Akuntansi Syariah (Jakarta: Renaisan, 2005), hlm, 13.

${ }^{47}$ Muhammad, Pengantar Akuntansi Syariah (Jakarta: Salemba Empat, 2002), hlm, 103. 
Tentu saja hal ini tidak terlepas dari proses konvergensi IFRS (International Financial Reporting Standards) yang telah dilakukan IAI terhadap standar akuntansi keuangan di Indonesia, membagi SAK ke dalam tiga pilar utama yaitu SAK Umum, SAK Syariah, dan SAK ETAP (Entitas Tanpa Akuntabilitas Publik). Sehingga secara umum koperasi di Indonesia menggunakan SAK ETAP, termasuk BMT yang secara legalitas berbadan hukum koperasi, hal ini mengacu pada Kementerian KUKM melalui Permen KUKM No.04/per/M.KUKM/VII/2012 tentang Pedoman Akuntansi Koperasi menetapkan bahwa koperasi menggunakan SAK ETAP.

Namun Mengingat BMT merupakan bagian dari entitas syariah yang juga melakukan sebagian besar transaksinya berbasis syariah, maka BMT diwajibkan menggunakan SAK Syariah, karena SAK ETAP tidak mengatur transaksi syariah, sedangkan untuk transaksi yang umum BMT dapat menggunakan SAK ETAP. Jadi secara umum BMT di Indonesia dapat menggunakan SAK Syariah dan SAK ETAP. Selain menggunakan SAK Syariah dan SAK ETAP, BMT dalam menjalankan proses akuntansi pada transaksinya juga merujuk pada peraturan-peraturan pemerintah yang berkaitan dengan pengaturan akuntansi untuk koperasi asal tidak bertentangan dengan prinsip syariah.

\section{Penutup}

Dari pengamatan di lapangan, bisa dikatakan BMT belum efisien secara keseluruhan. Beberapa permasalahan BMT sebagian besar terletak pada tata kelola manajemen, sumber daya manusia, laporan keuangan serta fungsi pengawasan. Inefisiensi terutama disebabkan dari biaya operasional dan biaya tenaga kerja. Beberapa BMT belum melakukan manajerial sumber daya manusia secara profesional. BMT belum melakukan efisiensi secara terstruktur dan terjadwal. Efisiensi hanya dilakukan dengan pengurangan biaya operasional dan perjalanan dinas. Sebagian besar BMT, BOPO melebihi ambang batas normal kesehatan perbankan. Belum ada standar baku dalam standar efisiensi, serta tidak adanya aturan dari pemerintah atau regulator dalam efisiensi terutama dalam laporan keuangan. Strategi efisiensi dilakukan terutama dalam pengurangan dan meminimalkan biaya perjalanan, tidak untuk biaya tenaga kerja. Selain itu, tata kelola manajemen SDM yang kurang profesional. 
Beberapa BMT mengelola SDM dengan tradisional, salah satunya merekrut karyawan dari unsur famili bukan dari kemampuan dan kepakarannya. Sehingga berimplikasi terhadap beban gaji karena menjadi biaya yang harus dikeluarkan karena minimnya kinerja yang dihasilkan pegawai. Walaupun begitu, sebenarnya efisiensi telah dilakukan dalam beberapa aspek operasional BMT secara tidak tertulis dan terekap dengan baik. Secara alamiah, BMT akan mengurangi pos beban pengeluaran jika dirasakan terjadi penurunan kas dan laba yang turun.

BMT sebagai lembaga keuangan syariah terus mengakomodasi kerangka syariah secara menyeluruh. Ia sebagai lembaga berbadan hukum koperasi diatur dengan peraturan KUKM. Selain itu pula mengacu pada PSAK. Pada awalnya ia mengacu PSAK 27, lalu dicabut oleh DSAK. Kemudian diganti dengan SAK syariah dan SAK ETAP. Namun Mengingat BMT merupakan bagian dari entitas syariah yang juga melakukan sebagian besar transaksinya berbasis syariah, maka BMT diwajibkan menggunakan SAK Syariah, karena SAK ETAP tidak mengatur transaksi syariah.

\section{Daftar Pustaka}

Afif, Wildan Syafik, and Darwanto. "Tata Kelola Baitul Maal Wa Tamwil (BMT) Studi Pada BMT Mekar Da ' Wah" 1, no. July (2017): 121-38.

Ali, M Mahbubi, Stei Tazkia, and Bank Indonesia. "Analisis Efisiensi Baitul Maal Wat Tamwil Dengan Pendekatan Two Stage Data Envelopment Analysis ( Studi Kasus Kantor Cabang BMT MMU Dan BMT UGT Sidogiri )" 5, no. 2 (2010): 110-25.

Almizan. "Pembangunan Ekonomi Dalam Perspektif Ekonomi Islam." Maqdis : Jurnal Kajian Ekonomi Islam 1, no. 2 (2016): 204-22.

Ascarya, D. Y, and S. R Guruh. Analisis Efisiensi Perbankan Konvensional Dan Perbankan Syariah Di Indonesia Dengan Data Envelopment Analysis (DEA). Jakarta: Prenada Media Group, 2009.

Ascarya, and Yumanita. "Comparing The Development of Islamic Financial / Bond Markets in Malaysia and Indonesia." Development, no. October (2016): 375-407.

Aziz, Amin. Pedoman Pendirian BMT. Jakarta: Pinbuk Press, 2004.

Berger, Allen N, and David B Humphrey. "Efficiency of Financial 
Institutions: International Survey and Directions for Future Research." European Journal of Operational Research 98 (1997): 175-212.

Dieter, Hans, and Dwi Agung. "Islamic Microfinance in Indonesia," 2006.

Hadad, Muliaman D, Wimboh Santoso, Eugenia Mardanugraha, and Dhaniel Illyas. Pendekatan Parametrik Untuk Efisiensi Perbankan Indonesia. Universitas Indonesia, 2003. Universitas Indonesia.

Harahap, Sofyan Safri. Auditing Dalam Perspektif Islam. Jaka: Pustaka Quantum, 2008.

Indra, Suhardjono Bastian. Akuntansi Perbankan. Jakarta: Salemba Empat, 2006.

Kasmir. Manajemen Perbankan. Jakarta: PT Raja Grafindo Persada, 2003.

Mangkuprawira, Sjafri. "Rumitnya Tata Kelola Perusahaan." Accessed June 25, 2021. http:/ / ronowajah.wordpress.com.

Masyithoh, Novita Dewi. "Analisis Normatif Undang-Undang No. 1 Tahun 2013 Tentang Lembaga Keuangan Mikro (Lkm) Atas Status Badan Hukum Dan Pengawasan Baitul Maal Wat Tamwil (Bmt)." Economica: Jurnal Ekonomi Islam 5, no. 2 (2014): 17-36. doi:10.21580/economica.2014.5.2.768.

Mingka, Agustianto. "Optimalisasi Dewan Pengawas Syariah." Accessed June 25, 2021. www.niriah.com.

Mughal, M. Z. "Empowering SMEs for Financial Inclusion and Growth." In Internasional Conference "Empowering SMEs for Financial Inclusion and Growth. Jakarta, 2014.

Muhammad. Pengantar Akuntansi Syariah. Jakarta: Salemba Empat, 2002.

Nasution, A. C. "Efficiency of Baitul Maal Wa Tamwil (BMT): An Effort towards Islamic Wealth Management in Microfinance Institution." The Journal of Muamalat and Islamic Finance Research 11, no. 1 (2014): 59-74.

Nisak, Badratun. "Analisis Manajemen Risiko Pembiayaan Musyarakah Pada Baitul Qiradh Bina Insan Mandiri Banda Aceh." Share 3, no. 1 (2014): 41-55.

Noor, Vini Sapta. Analisis Perbandingan Efisiensi Bank Syariah Dan Bank Konvensional Dengan Menggunakan Metode Data Envelopment Analysis (DEA), 2013. 
Nugroho, Nurfajdi Budi. "Studi PSAK Perbankan Syariah: Telaah Kesesuaian Dengan Prinsip Dan Nilai Syariah." Universitas Islam Indonesia, 2005.

OJK. "Statistik Perbankan Syariah." Departemen Perizinan Dan Informasi Perbankan, 2019. https://www.ojk.go.id/id/kanal/syariah/data-danstatistik/statistik-perbankan-syariah/default.aspx.

Prastiawati, Fitriani, and Emile Satia Darma. "Peran Pembiayaan Baitul Maal Wat Tamwil Terhadap Perkembangan Usaha Dan Peningkatan Kesejahteraan Anggotanya Dari Sektor Mikro Pedagang Pasar Tradisional." Jurnal Akuntansi Dan Investasi 17, no. 2 (2016): 197-208.

Putra, Purnama. "Analisis Tingkat Pemahaman Mahasiswa Terhadap Pernyataan Standar Akuntansi Keuangan Syariah PsakSyariah." JRAK 6, no. 01 (2015): 38-50.

Ramli, Hasbi. Edukasi Profesional Syariah, Teori Dasar Akuntansi Syariah. Jakarta: Renaisan, 2005.

Sakti, Ali. "Mapping of Condition and Potential of BMT: Partnership to Expand the Market and Linkage of Islamic Banking Services to the Micro Enterprises." Jurnal Al-Muzara'ah I, no. 1 (2013): 118.

Santoso, B.S. "Analisis Tingkat Kesehatan BMT Ditinjau Dari Aspek Manajemen." Jurnal Akuntansi-Bisnis $\mathcal{E}$ Manajemen 14, no. 4 (2003): 144-58.

Suseno, Priyonggo. "Analisis Efisiensi Dan Skala Ekonomi Pada Industri Perbankan Syariah Di Indonesia." Pusat Pengkajian Dan Pengembangan Ekonomi Islam 2 (2008): 25-55.

Sutawijaya, Adrian, and Etty puji Lestari. "Efisiensi Teknik Perbankan Indonesia Pascakrisis Ekonomi: Sebuah Studi Empiris Penerapan Model DEA." Jurnal Ekonomi Pembangunan 10, no. 1 (2009): 49-67.

Ula, N. “Analisis Implementasi Laporan Keuangan Berdasarkan SAK Syariah Pada Koperasi Perkreditan Rakyat Syariah (KPRS) AnNahl Pandaan." UIN Maulana Malik Ibrahim, 2019.

Yuningrum, Heny. "Mengukur Kinerja Operasional BMT Pada Tahun 2010 Ditinjau Dari Segi Efisiensi Dengan Data Envelopment Analysis (DEA) (Studi Kasus BMT Di Kota Semarang)." Jurnal Economica II, no. 2 (2012): 111-28. 